\title{
E-Summary Teaching Materials with Hannafin \& Peck Models for Training Participants in the Human Resources Development Agency
}

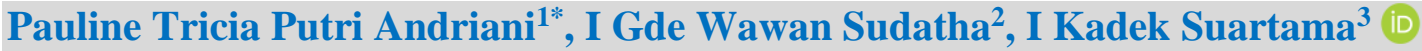 \\ ${ }^{1,2,3}$ Program studi Teknologi Pendidikan, Universitas Pendidikan Ganesha, SIngaraja, Indonesia \\ *Corresponding author: paulinetriciaputriandriani26@undiksha.ac.id
}

\begin{abstract}
Abstrak
Penelitian ini bertujuan untuk mendeskripsikan rancang bangun bahan ajar elektronik yang dikemas dalam bentuk esummary, dan untuk mengetahui validitas bahan ajar e-summary menurut para ahli dan uji coba produk. Jenis penelitian ini adalah penelitian pengembangan dengan model Hannafin \& Peck. Jenis data dalam penelitian ini adalah data kuantitatif dan kualitatif. Pengumpulan data penelitian menggunakan metode pencatatan dokumen dan metode kuesioner. Teknik analisis data yang digunakan adalah teknik analisis deskriptif kuantitatif, dan deskriptif kualitatif. Hasil penelitian (1) Rancang bangun bahan ajar e-summary ini terdiri dari pada tiga tahap yaitu Tahap analisis kebutuhan, Tahap desain, Tahap pengembangan dan implementasi. Dan pada setiap tahapannya melewati tahapan evaluasi. (2) Validitas pengembangan bahan ajar e-summary diukur melalui (a) hasil review ahli konten/isi dengan memperoleh persentase sebesar 93,3\% berada pada kualifikasi sangat baik, (b) hasil review ahli bahasa e-summary 87,5\% berada pada kualifikasi baik (c) hasil review dari uji coba perorangan menunjukan bahwa persentase keseluruhan subjek sebesar 97,1\% dengan kualifikasi sangat baik dan (d) hasil review uji coba kelompok kecil menunjukan bahwa persentase keseluruhan subjek sebesar 96,3\% dengan kualifikasi sangat baik. Secara umum hasil penelitian menunjukan bahwa e-summary valid dengan kualitas sangat baik dan layak digunakan pada proses pembelajaran dalam pelatihan diklat berpikir kreatif. Saran yang dapat diberikan dari hasil penelitian ini yaitu agar bahan ajar e-summary ini dapat digunakan secara optimal dalam proses pembelajaran sehingga dapat meningkatkan motivasi belajar mandiri peserta diklat serta mempermudah dalam memahami materi pelatihan.
\end{abstract}

Kata kunci: E-Summary, Pengembangan, Hannafin \& Peck.

\section{Abstract}

This study aims to describe the design of electronic teaching materials packaged in e-summary form, and to determine the validity of e-summary teaching materials according to experts and product trials. This type of research is development research using the Hannafin \& Peck model. The types of data in this study are quantitative and qualitative data. The research data collection used the document recording method and the questionnaire method. The data analysis technique used is descriptive quantitative analysis technique, and descriptive qualitative. The results of the study (1) The design of this esummary teaching material consists of three stages, namely the needs analysis stage, the design stage, the development and implementation stage. And at each stage it passes through the evaluation stage. (2) The validity of the development of esummary teaching materials is measured through (a) the results of the content/content expert review by obtaining a percentage of $93.3 \%$ being in very good qualification, (b) the results of the e-summary linguist review being $87.5 \%$ being on good qualifications (c) the results of the review of individual trials show that the percentage of the overall subject is $97.1 \%$ with very good qualifications and (d) the results of the small group trial review show that the percentage of the overall subject is $96.3 \%$ with very good qualifications. . In general, the research results show that e-summary is valid with very good quality and is suitable for use in the learning process in creative thinking training. Suggestions that can be given from the results of this study are that this e-summary teaching material can be used optimally in the learning process so that it can increase the training participants' self-study motivation and make it easier to understand the training material.

Keywords: E-Summary, Development, Hannafin \& Peck

$\begin{array}{ll}\text { History: } & \text { Publisher: Undiksha Press } \\ \text { Received : August 09, } 2021 & \text { Licensed: This work is licensed under } \\ \text { Revised : August 10, } 2021 & \text { a Creative Commons Attribution 3.0 License } \\ \text { Accepted : October 04, } 2021 & \text { CC (i) (O) } \\ \text { Published : October 25, } 2021 & \end{array}$

\section{INTRODUCTION}

Competence is a person's underlying characteristics that are causally related to effective and/or superior performance related to criteria in a job or situation (characteristics that underlie a person and affect the individual's effectiveness) (Huang et al., 2020; Supriyono, 2017). From this understanding of competence, it can be understood that 
competence is very inherent in a person because it is related to a person's characteristics and how effective a person is at work (Suciu \& Mata, 2011). Spencer explained the importance of increasing the ability and knowledge that supports one's effectiveness in work comes from the education and training process (Popescu et al., 2014; Snegurenko et al., 2019). An individual's competence is something inherent in him that can be used to predict his level of performance. What is meant can be related to motives, self-concepts, traits, knowledge as well as individual abilities/skills and competencies in the form of abilities and knowledge that can be developed through education and training (Ati, 2012; Linggi, 2021). Competency motives can be obtained during the selection process. From several previous opinions, it can be concluded that competency development is an effort to increase knowledge, skills, abilities, and thinking maturity, which automatically goes hand in hand with changes in morals and behavior in carrying out government and development tasks (Ati, 2012; Sormin, 2016). The device must be able to provide services to the community in a fair and transparent manner and be able to demonstrate loyalty, commitment, and work ethic, as well as high integrity. This task is carried out if it is supported by the technical competence of the device. Ironically, the existence of professional apparatus in various public institutions is still limited, so serious attention is needed so that the implementation of government duties and public services can be carried out optimally (Darmadi, 2016; Wahyono et al., 2020).

The Human Resources Training Agency or often abbreviated as BPSDM as one of the agencies that organize training for apparatus human resource development in Bali Province, of course, is also sensitive to problems that occur in the field, in an interview with one of the Widyaiswara stated the same statement that the development of apparatus competence is still not optimal. Seeing the conditions that occurred, the Bali Provincial Government issued a policy on Governor Regulation No. 7 of 2020 concerning "One Stop Competence Development", to answer the problems and policies of the Bali Provincial Government, the Bali Provincial Human Resources Development Agency has a strategy of realizing digitalbased competency development. The development of digital-based competencies will of course also affect the use of learning tools used during training. Widyaiswara BPSDM Bali Province as educators, instructors, and trainers for training participants are required to be more innovative in using digital-based learning tools.

Based on the results of distributing questionnaires to find out the obstacles that occurred in the training and education, they received a response that the use of printed teaching materials during the current covid-19 pandemic was not effective so that $81.1 \%$ or 9 out of 11 Widyaiswara needed other alternatives to store and distribute materials more flexible and effective teaching by utilizing technology. Then the teaching materials used in the training still use simple printed and PowerPoint teaching materials, this is due to limited mastery and IT infrastructure is one of the major factors for not providing more optimal digital-based training, as evidenced by $71.7 \%$ or 8 of 11 Widyaiswara have not been able to make technology-based teaching materials. In addition, the density of the material makes it difficult for participants to understand the subject presented by the speaker in a very limited time. In other words, $100 \%$ or 30 of the 30 training participants need more concise learning resources so that they are easy to understand independently. There is a gap between the real condition and the expected condition, so if it is not followed up, it is feared that it could have an impact on the low motivation, interest, and student learning outcomes, one of the alternatives to increase the motivation of training participants and optimize the use of available technological facilities, as well as adjust the continuity of the training process with the current development of science and technology is to facilitate the learning process with ICT-based teaching materials (Purwanto \& Rizki, 2015; Taqiyyah et al., 2017).

Seeing the development of information and communication technology that develops in all aspects, allows the development of teaching materials with digital-based technology in 
the form of e-summary teaching materials or electronic summaries as alternative teaching materials in supervisory leadership training on creative thinking materials (Butow \& Hoque, 2020; Saidah \& Damariswara, 2019). Summary or summary is a short writing that has the aim of making the reader understand. This study aims to describe the design of electronic teaching materials packaged in e-summary form, and to determine the validity of e-summary teaching materials according to experts and product trials.

\section{METHODS}

This research can be development research in learning disciplines. This research was carried out at the Bali Province Human Resources Development Agency in the Supervisory Leadership Training for creative thinking materials. The topic of this research is the training participants, totaling 30 participants. The development procedure used refers to the Hannafin $\&$ Peck model. In this model, all phases involve an evaluation and revision process. This model is more product-oriented, through three phases: namely: the analysis phase, the design phase, the development and implementation phase (Tegeh et al., 2015).

The subjects of this study were 1) content experts for training materials, 2) language experts for e-summary teaching materials. Content experts are education and training speakers who are in charge of e-summary materials in leadership training to review esummary products developed, and this e-summary writing linguist is asking for the availability of Indonesian literature lecturers who are experts in the field of writing to review the use of the developed e-summary discussion. For individual trials consisting of 1-3 people to obtain initial input about the product being developed, the three training participants consist of one training participant with high post-test results, one training participant with moderate post-test results, and one training participant with high post-test results. The difference in the learning outcomes of the training participants is seen in the list of post-test scores owned by the Widyaiswara. Then the subject for a small group trial consisting of 6-12 people (Tegeh \& Jampel, 2017). The small group trial subjects in this study amounted to 6 training participants. The six people consisted of two people having a high post-test, two people having a moderate post-test, and two people having a low post-test. learning achievement concerned seen post-test evaluation conducted at the end of the training.

At this stage there are several concepts that are designed, namely: At this stage there are several concepts that are designed, namely: (1) designing flowcharts, (2) designing storyboards (3) preparing learning designs, these components are designs in developing elearning material products. -summary, (4) a grid of exercise assessment instruments. Instruments are tools or facilities used by researchers in collecting data so that their work is easier and the results are better, in the sense of being more accurate, complete, and systematic, so that they are easy to process (Arikunto, 2013). The instrument was developed using a Likert scale with 5 scales. The lowest score was assigned a score of 1 and the highest score was assigned a score of 5 . The instrument was used to obtain data from expert reviews and individual and small group trials. The lattice instruments used in this study are Table 1, Table 2, and Table 3.

Table 1. Grid of Expert Instruments Content of Electronic Teaching Materials

\begin{tabular}{lllc}
\hline No & Aspect & \multicolumn{1}{c}{ Indicators } & $\begin{array}{c}\text { Number } \\
\text { of Items }\end{array}$ \\
\hline 1. & Material & Material compatibility with learning objectives. & 2 \\
& Structure & $\begin{array}{l}\text { The suitability of the material with the indicators. } \\
\text { The suitability of the material with the description of the } \\
\text { training subjects. }\end{array}$ & 3 \\
\hline
\end{tabular}




\begin{tabular}{lllc}
\hline No & Aspect & \multicolumn{1}{c}{ Indicators } & $\begin{array}{c}\text { Number } \\
\text { of Items }\end{array}$ \\
\hline 2. & Contents & Clarity of presentation of material. & 2 \\
& & Use of relevant illustrations/examples. \\
& $\begin{array}{l}\text { The presentation of learning materials is easy to } \\
\text { understand. }\end{array}$ & 2 \\
& Completeness of material presentation. & 1 \\
\hline & \multicolumn{1}{c}{ Total } & 3 \\
\hline
\end{tabular}

Table 2. Grid of Linguists Instruments for Electronic Teaching Materials

\begin{tabular}{cclc}
\hline No & Aspect & \multicolumn{1}{c}{ Indicators } & Number of Items \\
\hline 1. & Language & The sentence structure used is easily understood by & 2 \\
& Usage & the training participants. & 3 \\
& Use short, concise, and clear sentences. & 3 \\
& Effective use of potassium. & 2 \\
& Active verbs to animate writing. & 2 \\
\hline & Compilation of paragraphs. & 12 \\
\hline
\end{tabular}

Table 3. Grid of Product Trial Instruments Individually and in Small Groups

\begin{tabular}{|c|c|c|c|}
\hline No & Aspect & Indicators & $\begin{array}{l}\text { Number of } \\
\text { Items }\end{array}$ \\
\hline 1. & User Friendly & Ease in using electronic teaching materials & 1 \\
\hline 2. & Stand Alone & $\begin{array}{l}\text { The use of e-summary does not depend on } \\
\text { other teaching materials }\end{array}$ & 1 \\
\hline \multirow[t]{4}{*}{3.} & Content & Clarity of the material presented the material & 2 \\
\hline & Representation & presented is easy to understand & 1 \\
\hline & & Presented visual appeal & 1 \\
\hline & & E-summary can increase learning motivation & 1 \\
\hline \multirow[t]{3}{*}{4.} & Language & Use short, concise, and clear sentences. & 1 \\
\hline & & Effective use of sentences. & 1 \\
\hline & & $\begin{array}{l}\text { The language used in the teaching materials } \\
\text { is easy to understand and communicative }\end{array}$ & 1 \\
\hline \multirow[t]{3}{*}{5.} & Technical & $\begin{array}{l}\text { Using an autoresponder makes it easier for } \\
\text { me to access the e-summary }\end{array}$ & 1 \\
\hline & & $\begin{array}{l}\text { Instructions for using teaching materials are } \\
\text { clear }\end{array}$ & 1 \\
\hline & & Total & 12 \\
\hline
\end{tabular}

There are two data analysis techniques used in this study, namely research data which is processed using quantitative descriptive data analysis techniques, this analysis technique is used to process data obtained through questionnaires in the form of descriptive percentages and qualitative descriptive analysis is used to process data from content experts' reviews. study or material, linguists and individual and small group product testing, this data analysis technique is carried out by grouping information from qualitative data in the form of input, feedback, criticism and suggestions for improvement contained in the questionnaire and interview results (Agung, 2014). The results of this analysis are then used to revise the products developed as in the following study. This implementation process to seek validity with the subject of this study consisted of 3 expert experts, 6 small group students and 3 
individual test students. The analysis used in this research is quantitative descriptive analysis by collecting scores through a questionnaire test. To be able to give meaning in decision making, the provisions or references are used as in Table 4.

Table 4. Instrumental Achievement Level Scale with Five Scale

\begin{tabular}{cc}
\hline Achievement level (\%) & Qualification \\
\hline $90-100$ & Very good \\
$75-89$ & Good \\
$65-74$ & Enough \\
$55-64$ & Not enough \\
$0-54$ & Very less \\
\hline & (Tegeh et al., 2015)
\end{tabular}

\section{RESULTS AND DISCUSSION}

\section{Results}

The results of this study indicate that the e-summary teaching materials developed have passed the development stage and have been validated by experts and have been tested on training participants. In its development, this e-summary teaching material has been declared valid with very good and good quality so that it is suitable to be used to assist training participants in learning creative thinking training materials in supervisory leadership training at BPSDM Bali Province. The very good quality of this e-summary teaching material is obtained due to the following things. This e-summary teaching material was developed based on the results of a needs analysis and was developed with a systematic development model that is based on a theoretical foundation. The selection of the Hannafin and Peck model in the process of developing e-summary teaching materials is because the learning model is very simple and can carry out a continuous evaluation at every stage of development. This development model also provides an opportunity for developers to continuously evaluate and review each phase it goes through so that it has an impact on the validity of the e-summary product that is produced and is suitable for the learning process during the training process. The results of the reviews from content experts, linguists, individual trials, small group trials are presented in Table 5.

Table 5. Results of the e-summary validity review

\begin{tabular}{clcc}
\hline No & \multicolumn{1}{c}{ Trial Subject } & Validity Results & Description \\
\hline 1 & Content expert/Learning content & $87,5 \%$ & Good \\
2 & Linguist & $93,3 \%$ & Very good \\
3 & Individual Trial & $97,1 \%$ & Very good \\
4 & Small Group Trial & $96,35 \%$ & Very good \\
\hline
\end{tabular}

The results of the analysis show that e-summary teaching materials according to content experts are $93.3 \%$ with very good validity qualifications, according to linguists esummary teaching materials are $87.5 \%$ with good qualifications, according to individual trial subjects it is $97,1 \%$ with very good qualifications, and according to the small group trial subject $96.35 \%$ with very good qualifications. Through the results of the validity test, the esummary product gets suggestions, input, and comments which can then be used as a 
reference for revising the e-summary product. The results of product development are shown in Figure 1, Figure 2, Figure 3, and Figure 4.

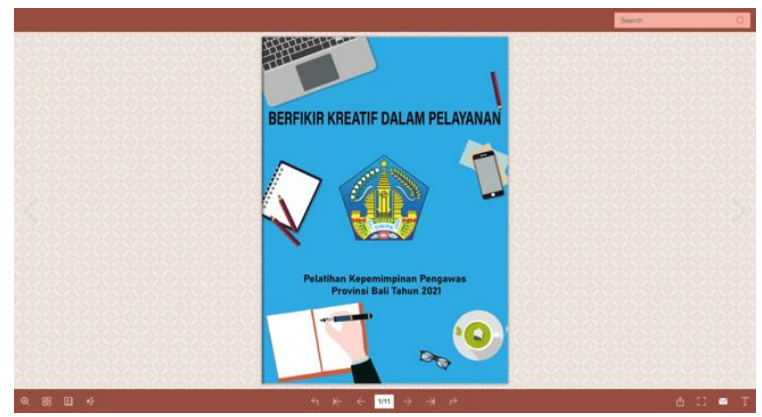

Figure 1. Cover

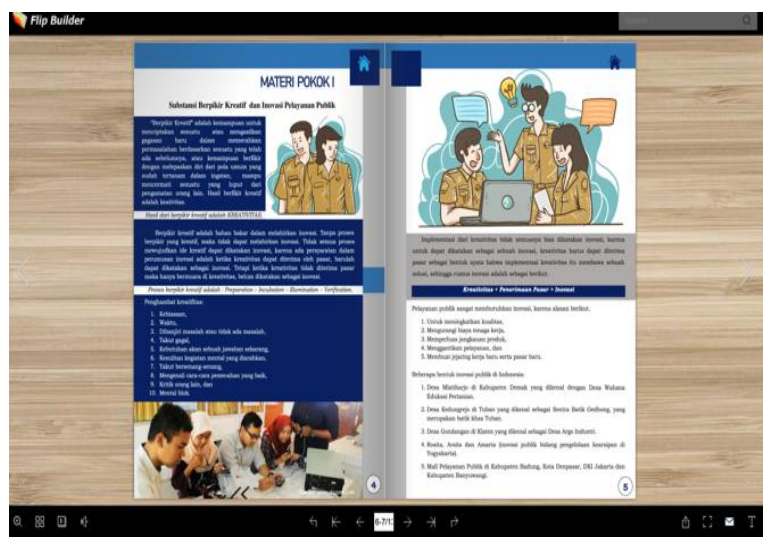

Figure 3. Content of E-Summary

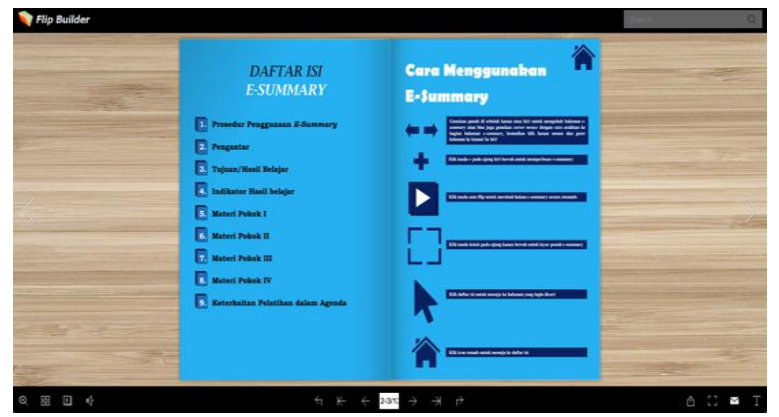

Figure 2. Table of Content

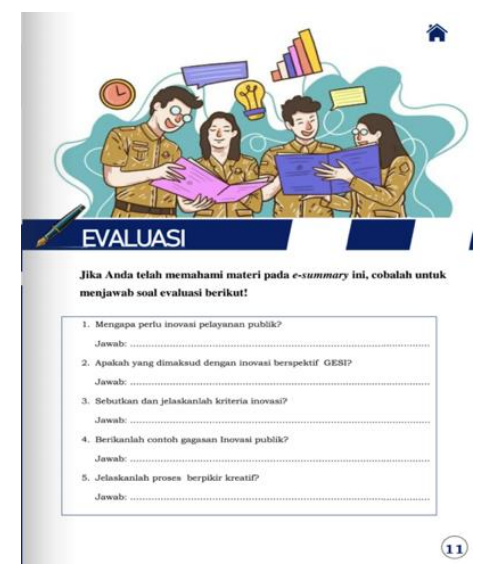

Figure 4. Evaluation Sheet

\section{Discussion}

Based on further studies, there are several important aspects that affect the validity of the developed e-summary teaching materials. The aspects in question are e-summary material aspects and e-summary language aspects. Judging from the results of the review of the content/contents expert test of e-summary teaching materials, it is known that the percentage result of the level of achievement of learning content/content expert results is $93.3 \%$ so that it is in a very good qualification, due to the suitability between the presentation of the material and the formulation of basic competencies, indicators, and learning objectives and conformity with the structure of the material with the truth of the substance, the accuracy of concepts and definitions, depth and breadth of the material. This is evidenced by the results of the presenter's assessment. The evaluation of individual and small group trial trainees on instrument items on the suitability of the material and the accuracy of the structure of the material also resulted in a percentage $(97.1 \%)$ with very good criteria, in individual experiments and very good criteria $(96.35 \%)$ in small group studies. From this, it can be concluded that the presentation of the material in the summary of didactic material is in accordance with the basic competence requirements, indicators, and learning objectives that must be achieved by training participants. This is in accordance with the opinion that in evaluating aspects of teaching materials, it is necessary to pay attention to the suitability of materials with learning objectives because these components can be linked to producing good teaching materials (Astra et al., 2020; Juniarti, 2019). Very good validity qualifications in the aspect of the subject matter were also obtained because of the suitability of the use of visualization in the delivery of material in e-summary teaching materials. 
Judging from the language aspect of e-summary teaching materials, the validity of esummary based on the results of reviews from linguists, it is known that e-summary teaching materials are in good qualification, with an achievement rate of $87.5 \%$ being in good qualifications. Obtaining language qualifications in e-summary teaching materials such as compatibility with the use of written language in accordance with Indonesian language rules, effective and efficient use of language, grammatical accuracy, clarity of information, and straightforward language. This is evidenced by the results of the assessment by the linguist test which resulted in the evaluation of the training participants in individual and small group trials on instrument items in relation to the use of language in writing test didactic materials reached a percentage $(97.1 \%)$ with very good criteria in individual research and very good criteria $(96.35 \%)$ in small group research. this grammar, clarity of information, and straightforward language are appropriate and appropriate and can clarify the learning message conveyed to the training participants. This is in line with the opinion that mentions things that need to be considered regarding the use of language in the manufacture of electronic teaching materials, namely: (1) the selection of a variety of languages; (2) word selection; (3) the use of effective sentences; (4) the preparation of meaningful paragraphs. This statement is also proven through research results which state that aspects of making electronic teaching materials need to pay attention to the use of language effectively and efficiently, grammatical accuracy, clarity of information, and straightforward language (Afifah et al., 2016; Minawati et al., 2014).

Judging from the results of reviews by training participants on individual and small group trials, the e-summary teaching materials developed are in very good qualifications. Obtaining very good qualifications from individual trials and small group trials because the use of auto responder-based e-summary is packaged in an attractive and very effective manner so that it can increase learning motivation and make it easier for students to understand the material independently. This is evidenced from the results of the assessment of individual test subjects and small group test subjects on instrument items related to writing material presented in accordance with what was learned during interesting training, the material presented is in accordance with competency standards and learning objectives, systematic presentation of material in teaching materials makes it easier for participants education and training to understand the overall material, the use of this e-summary facilitates the learning process in training, this is evidenced by the results of the percentage gain $(97.1 \%)$ with very good criteria in individual trials, and very good criteria $(96.3 \%)$ in small group trial. So it can be concluded that the use of e-summary teaching materials is very helpful for training participants in understanding training materials independently in a short time. This is in line with the opinion which states that the summary has a potential effect in improving students' abilities and understanding, thus helping the learning process (Nurzaelani et al., 2018; Yani, 2016).

\section{CONCLUSION}

The design of this e-summary teaching material consists of three stages, namely the needs analysis stage, the design stage, the development, and the implementation stage. And at each stage, it passes through the evaluation stage. The validity of the development of esummary teaching materials is measured through (1) the results of the content/content expert review by obtaining a percentage of $93.3 \%$ being in very good qualifications, (2) the results of the e-summary linguist review being $87.5 \%$ being on good qualifications and (3) on the results of a review of individual trials showed that the overall percentage of subjects was $97.1 \%$ with very good qualifications. The evaluation results from the small group trial showed that the overall percentage of subjects was $96.3 \%$ with very good qualifications. 


\section{REFERENCES}

Afifah, E., Triyono, T., \& Hotifah, Y. (2016). Pengembangan Media Letter Sharing Untuk Meningkatkan Keterampilan Komunikasi Siswa Introvert. Jurnal Kajian Bimbingan Dan Konseling, 1(2), 27-32. https://doi.org/10.17977/um001v1i12016p027.

Agung, A. A. G. (2014). Buku Ajar Metodelogi Penelitian Pandidikan. Aditya Media Publishing.

Arikunto, S. (2013). Dasar-Dasar Evaluasi Pendidikan. Bumi Aksara.

Astra, I. M., Raihanati, R., \& Mujayanah, N. (2020). Development of Electronic Module Using Creative Problem-Solving Model Equipped with Hots Problems on The Kinetic Theory of Gases Material. Jurnal Penelitian \& Pengembangan Pendidikan Fisika, 6(2), 181-194. https://doi.org/10.21009/1.06205.

Ati, R. (2012). Pengaruh Kompetensi Dan Komitmen Guru Pendidikan Kewarganegaraan Dalam Mengimplementasikan Pendidikan Karakter Terhadap Hasil Belajar Siswa: Studi Deskriptif di SMP Negeri Kota Bandung. Universitas Pendidikan Indonesia.

Butow, P., \& Hoque, E. (2020). Using artificial intelligence to analyse and teach communication in healthcare. Breast, 50, 49-55. https://doi.org/10.1016/j.breast.2020.01.008.

Darmadi, H. (2016). Tugas, peran, kompetensi, dan tanggung jawab menjadi guru profesional. Edukasi: Jurnal Pendidikan, 13(2), 161-174. http://www.journal.ikippgriptk.ac.id/index.php/edukasi/article/view/113.

Huang, S. Y., Kuo, Y. H., \& Chen, H. C. (2020). Applying digital escape rooms infused with science teaching in elementary school: Learning performance, learning motivation, and problem-solving ability. Thinking Skills and Creativity, 37(129), 100681. https://doi.org/10.1016/j.tsc.2020.100681.

Juniarti, Y.-A. J. P. (2019). Pengembangan Media Ludo Geometri (DORI) pada Fisik Motorik Anak Usia Dini. Al-Athfal Jurnal Pendidikan Anak, 5(2), 169-182. https://doi.org/https://doi.org/10.14421/al-athfal.2019.52-04.

Linggi, Y. (2021). Pengaruh Kompetensi dan Motivasi Kerja Terhadap Kinerja Guru Otomotif SMK Kristen Tagari Toraja Utara. Jurnal Pendidikan Tambusai, 5(1), 507513. https://doi.org/10.33603/jibm.v3i1.2191.

Minawati, Z., Haryani, S., \& Pamelasari, S. D. (2014). Pengembangan Lembar Kerja Siswa IPA Terpadu Berbasis Inkuiri Terbimbing Pada Tema Sistem Kahidupan Dalam Tumbuhan Untuk Smp Kelas VIII. In USEJ - Unnes Science Education Journal (Vol. 3, Issue 3, pp. 587-592). https://doi.org/10.15294/usej.v3i3.4265.

Nurzaelani, M. M., Kasman, R., \& Achyanadia, S. (2018). Pengembangan Bahan Ajar Integrasi Nasional Berbasis Mobile. Jurnal Teknologi Pendidikan, 20(3).

Popescu, A.-D., Suciu, S., \& Raoult, M.-G. (2014). Intercultural Competences in Collaborative Teams. Procedia Technology, 12, 577-582. https://doi.org/10.1016/j.protcy.2013.12.532.

Purwanto, Y., \& Rizki, S. (2015). Pengembangan Bahan Ajar Berbasis Kontekstual Pada Materi Himpunan Berbantu Video Pembelajaran. AKSIOMA Journal of Mathematics Education, 4(1), 67-77. https://doi.org/10.24127/ajpm.v4i1.95.

Saidah, K., \& Damariswara, R. (2019). Pengembangan Bahan Ajar Materi Dongeng Berbasis Kearifan Lokal Jawa Timur Bagi Siswa Kelas III SD. Premiere Educandum : Jurnal $\begin{array}{llll}\text { Pendidikan Dasar Dan } & 73 .\end{array}$ https://doi.org/10.25273/pe.v9i1.4320.

Snegurenko, A. P., Sosnovsky, S. A., Novikova, S. V., Yakhina, R. R., Valitova, N. L., \& Kremleva, E. S. (2019). Using e-learning tools to enhance students-mathematicians' competences in the context of international academic mobility programmes. 
Integration of Education, 23(1), 8-22. https://doi.org/10.15507/19919468.094.023.201901.008-022.

Sormin, D. (2016). Kompetensi Guru Dalam Melaksanakan Dan Mengelola Proses Belajar Mengajar Di Pondok Pesantren Darul Mursyidi Desa Sialogo Tapanuli Selatan. FITRAH:Jurnal Kajian Ilmu-Ilmu Keislaman, 2(1), 117. https://doi.org/10.24952/fitrah.v2i1.459.

Suciu, A. I., \& Mata, L. (2011). Pedagogical Competences - The Key to Efficient Education. International Online Journal of Educational Sciences, 3(2), 411-423. https://www.acarindex.com/dosyalar/makale/acarindex-1423904375.pdf.

Supriyono, A. (2017). The Influence Of Pedagogic, Professional Competency, And Work Motivation Onteacher Performance Of Elementary School. Jurnal Pendidikan, 18(2), $1-12$.

Taqiyyah, S. A., Subali, B., \& Handayani, L. (2017). Implementasi Bahan Ajar Sains Berbahasa Inggris Berbasis Metakognitif Untuk Meningkatkan Kemampuan Pemecahan Masalah Siswa SMP. Jurnal Inovasi Pendidikan IPA, 3(2), 224-234. https://doi.org/10.21831/jipi.v3i2.14859.

Tegeh, I. M., \& Jampel, I. N. (2017). Metode Penelitian Pengembangan. Universitas Pendidikan Ganesha.

Tegeh, M., Pudjawan, K., \& Jampel, N. (2015). Model Penelitian Pengembangan. Graha Ilmu.

Wahyono, P., Husamah, H., \& Budi, A. S. (2020). Guru profesional di masa pandemi COVID-19: Review implementasi, tantangan, dan solusi pembelajaran daring. Jurnal Pendidikan Profesi Guru, 1(1), 51-65. http://ejournal.umm.ac.id/index.php/jppg/article/view/12462.

Yani, R. (2016). Pengembangan Instrumen dan Bahan Ajar untuk Meningkatkan Kemampuan Komunikasi, Penalaran, dan Koneksi Matematis dalam Konsep Integral. Jurnal Penelitian Pendidikan, 13(1), 44-52. 